\title{
Lysine-Specific Demethylase 2B
}

National Cancer Institute

\section{Source}

National Cancer Institute. Lysine-Specific Demethylase 2B. NCI Thesaurus. Code C120059.

Lysine-specific demethylase 2B (1336 aa, $\sim 153 \mathrm{kDa})$ is encoded by the human KDM2B gene. This protein is involved in the demethylation of lysine- 4 and lysine-36 in histone H3. 